результати роботи [3, с. 67].

Під час проведення досліду учні порівнювали рослини 3 контрольними i переконувалися, що без спостережень вони не встановили б, який уплив на рослини має вдобрення грунту, підживлення тощо. Догляд за рослинами і спостереження учні вели позаурочно за підготовленим планом. Користуючись цим планом, учні без труднощів проводили спостереження і записували у своїх щоденниках їх результати.

Така організація проведення дослідів на навчально-дослідній ділянці давала можливість охопити роботою всіх учнів і мала позитивні результати в засвоєнні ними теоретичного матеріалу і набуванні практичних умінь.

Вивчення досвіду організації дослідної роботи в українській загальноосвітній школі у другій половині XX ст. показало, що дослідна робота використовувалась переважно для підвищення якості знань з предметів біологічного циклу (ботаніки, зоологіі), основ сільськогосподарського виробництва, була спрямована на зміцнення зв'язку навчання $з$ трудовою діяльністю учнів, охоплювала навчальний, позакласний i позашкільний час і мала навчальну, виробничу і наукову значущість. Нині необхідно критично переосмислити наявний педагогічний досвід, адже раціональне використання доробку наших попередників сприятиме розбудові загальноосвітньої школи. Надбання минулого доцільно наповнити сучасним науковим змістом, обрати ті шляхи та форми організації дослідної роботи, які сприятимуть удосконаленню навчально-виховного процесу і допомагатимуть виходу України на світовий рівень у галузі освіти і науки.

До перспектив подальших розвідок в окресленому напрямі слід віднести вивчення особливостей організації дослідної роботи в загальноосвітній школі у незалежній Україні.

\title{
Література
}

1. Денисюк О. Л. Навчально-дослідна робота учнів у шкільному саду / О. Л. Денисюк. - К. : Рад. школа, 1960. - 104 с. 2. Дослідницька робота в школі / [упоряд. У. А. Тюпа, Є. Д. Видро, Н. М. Шаповал; за ред. У. А. Тюпи]. К. :Рад. школа, 1962. - 132 с. З. Методика и тематика опытнической работы кружков юных натуралистов и ученических учебно-производственных бригад/[сост. К. Ф. Руденко, А. М. Шерман, Д. А. Яковлев]. - Луганск, 1960. - 42 с. 4. Організація дослідницької роботи з зерновими культурами в школі / [упоряд. М. Я. Ліцовський, С. А. Клименко]. - К. : Рад. школа, 1965. - 14 с. 5. Процик И. И. Формирование исследовательских умений и навыков у учащихся сельской школы : дис. ... канд. пед. наук / Иван Игнатьевич Процик. - К., 1977. - 164 с. 6. Учебно-опытная работа юных натуралистов-мичуринцев (из опыта работы кружка юннатов Лантратовской семилетней школы Троицкого района)/[упоряд. Ф. Ф. Пенчев]. - Ворошиловград, 1952. -42 c.

\section{УПРОВАДЖЕННЯ ВЕРБАЛЬНО-ГРАФГЧНИХ МЕТОДІВ НАВЧАННЯ У ПЕДАГОГІЧНІЙ СПАДЩИНІ С. ШЕВЧЕНКА}

Москальова О. I. Упровадження вербально-графічних методів навчання у педагогічній спадщині С. Шевченка.

У статті досліджено й узагальнено досвід вітчизняного педагога-новатора С. Шевченка щодо розроблення теоретичних засад та впровадження вербальнографічних методів навчання. Проаналізовано позитивні сторони використання структурно-логічних схем на різних етапах навчального процесу, підкреслено доцільність їх подальшого вдосконалення та використання у навчально-виховному 
процесі сучасної школи.

Ключові слова: навчальний процес, абстрактно-символічна наочність, вербальнографічний метод, лист опорних сигналів, педагог-новатор.

Москалева О.И. Внедрение вербально-графических методов обучения в педагогическом наследии С. Шевченко.

В статье исследован и обобщен опыт отечественного педагога-новатора С. Шевченко в области разработки теоретических основ и внедрения вербальнографических методов обучения. Осуществлен анализ положительных сторон использования структурно-логических схем на разных этапах учебного процесса, подчеркнута целесообразность их дальнейшего совершенствования и использования в учебно-воспитательном процессе современной школы.

Ключевые слова: учебный процесс, абстрактно-символическая наглядность, вербально-графический метод, страница опорных сигналов, педагог-новатор.

Moskalyova O. I. The Implementation of the Verbal and Graphic Teaching Methods in Pedagogical Heritage of S. Shevchenko.

In the article there is analyzed and summarized the experience of the native pedagogue-innovator S. Shevchenko concerning the development of the theoretical bases and the implementation of the verbal and graphic teaching methods.There are investigated the positive sides if using the structural and logical schemes at the different level of the learning process, there is underlined the reasonability of their further implementation and the use in the educational and upbringing process of modern school.

Key words: learning process, abstract-symbolic use of visual methods, verbal and graphic method, list of reference signals, pedagogue-innovator.

В умовах модернізації сучасної вітчизняної педагогіки важливого значення набуває оновлення цілей та змісту освіти. Згідно 3 вимогами часу зростає потреба в ефективних педагогічних технологіях, здатних забезпечити повноцінне сприйняття, поглиблене та міцне засвоєння змістовно-цілісних, завершених блоків навчального матеріалу, позитивно впливати на мотивацію учнів, значно активізувати розумову діяльність, надавати можливості формування сприятливого психологічного клімату. Зміни в державній освітній політиці України надають змогу педагогічним колективам апробувати та використовувати досягнення як сучасної дидактики, нових педагогічних технологій, так і досягнень минулого.

Загальні прийоми застосування різноманітних типів наочності в поєднанні 3 методами усного викладу навчального матеріалу розроблені відомими радянськими дидактами А. Алексюком, Ю. Бабанським, А. Вагіним, М. Даниловим, Б. Ссиповим, Л. Занковим, І. Лернером, В. Лозовою, Л. Нечепоренко, В. Онищуком, М. Скаткіним, А. Столяром, Л. Фрідманом, Г. Щукіною та ін. Науковці розширили підходи до розуміння та використання наочності, обгрунтували необхідність застосування в ролі наочних образів різноманітних знакових моделей, схем, таблиць, графіків, символів, тощо $[1 ; 3 ; 4 ; 5 ; 6 ; 7]$. Різні аспекти застосування структурно-логічних схем у процесі пізнання, вплив абстрактно-символічної наочності на ступінь пізнавальної активності учнів досліджені В. Болтянським, В. Вакурко, М. Винокур, А. Добишевим, Б. Порусом, Д. Столярчуком, В. Сухомлинським, Н. Силич, Л. Фрідманом, П. Ендрієвим, I. Якиманською та ін. Отже, зростання ролі абстрагованих, символічних зображень спричинило їх виокремлення в окрему групу наочності та суттєво вплинуло на активізацію пошуків прийомів стислого перекладу великого обсягу інформації 3 вербальної системи у графічну. Результатом цієї грунтовної праці стала поява 
сутнісних, принципових змін у традиційній організації проведення навчального процесу. Зокрема педагогами-новаторами 70-90 pp. XX ст. М. Винокур, Р. Зубчевською, Д. Меженком, В. Шаталовим, С. Шевченком, В. Шейманом та іншими було знайдено та практично перевірено кілька форматів поєднання вербальних і графічних методів навчання.

Метою статmі є вивчення, узагальнення та ретроспективний аналіз освітньої технології впровадження вербально-графічних методів навчання у педагогічній діяльності вчителя-новатора С. Шевченка.

Досліджуючи перспективні педагогічні технології, слід згадати талановитого вчителя історії, послідовника ідей В. Шаталова, педагога-новатора С. Шевченка. Досвідчений учитель виступав проти авторитарного стилю педагогічного спілкування. Його погляди грунтувалися на досвіді видатного педагога-новатора В. Шаталова та стали основою для розроблення та використання авторської, оригінальної системи організації навчально-виховного процесу, що значно підвищувала якість навчання. С. Шевченко зазначав, що «педагогічний процес у формі вчительсько-учнівської діяльності може здійснюватися у вигляді різних комбінацій, тобто у формі різних технологій», і чітке дотримування структури цього процесу дозволить отримати заплановані результати [9, с. 73].

Сутність педагогічної технології С. Шевченка полягає в неперервності та цілісності процесу пізнання, варіативності методів навчання, співробітництві вчителя з учнями, учнів між собою, орієнтації навчального процесу на розвиток самостійності, відповідальності, творчої активності учнів.

Розкриємо особливості самоуправління та самодіяльності учнів у навчанні, забезпечення корегувальних функцій учителя відповідно до технології С. Шевченка. В кожному класі обиралася постійна група 3 дев'яти учнів, обов'язками яких була перевірка зошитів, заповнювання екрану успішності, забезпечення наявності на уроці листів опорних сигналів, призначення на кожен урок «головуючого вчителя», контроль правильності заповнення екрану успішності та оцінок в зошитах учнів, призначення консультантів для слабковстигаючих учнів. Періодично група самоуправління обговорювала свою роботу та звітувалася перед класом. Отже, саме широка, творча участь учнів в організації та проведенні навчального процесу $\epsilon$ визначальною в педагогічній системі С. Шевченка. Можна погодитися 3 Л. Фрідманом, який зазначав, що вся робота С. Шевченка грунтується на довірі до учнів, які іiі цінують і не припускають завищення оцінок. А деякі неточності в оцінюванні може допустити навіть і вчитель [8, с. 93].

Новаторська методика С. Шевченка передбачала, що за одиницю навчального матеріалу брався не урок, а логічно завершений розділ навчальної програми, який розраховувався на сім - десять уроків. Вивчення такого розділу поділялося на два етапи. Перший етап - отримання учнями нових знань та їх засвоєння, що охоплював п’ять - сім уроків. Другий етап - систематизація та узагальнення отриманих знань, складання учнями заліку за розділом, що охоплював два - три уроки. На кожному уроці першого етапу вивчалася окрема тема в межах загальної теми розділу. Однак використовувалися суттєво нові методичні прийоми [2]. Вивчення кожної теми передбачало три етапи: 1) пояснення вчителем нового навчального матеріалу в другій половині уроку; 2) домашня індивідуальна робота учнів 3 новою навчальною інформацією; 3) актуалізація та контроль засвоєння знань в першій половині наступного уроку. Запропонований алгоритм роботи сприяв максимальному наближенню навчального процесу до природних психологічних властивостей людського сприйняття. 
Педагог-новатор систематично та активно використовував в навчальному процесі оригінальні наочні посібники - листи опорних сигналів, призначенням яких було попередження забування матеріалу та його закріплення у той же день. Схарактеризуємо більш детально цей аспект новаторської методики С. Шевченка.

Вивчення нової теми педагог розпочинав у другій половині уроку, детально пояснюючи зміст теми, виділяючи найбільш важливі поняття та факти, звертаючи увагу учнів на особливості цієї теми. Після пояснення вчитель демонстрував учням певну конспект-схему (лист опорних сигналів) нової теми. Потім удруге швидко та чітко, користуючись конспект-схемою, повторював зміст навчального матеріалу. Після цього учні перерисовували конспект-схему в свої домашні зошити. Підводячи підсумки, вчитель ще раз повторював зміст навчальної теми за опертям на листи опорних сигналів.

Наступний етап технології С. Шевченка - закріплення нової теми. Ця робота виконувалася учнями вдома за чітко встановленою послідовністю: прочитати, подумки проговорити зміст прочитаного, зіставити інформацію з розповіддю вчителя та конспект-схемою. Слід зазначити, що заздалегідь спланована, незмінна структура роботи над навчальною темою вдома надавала учням можливість обирати темп роботи відповідно до індивідуальних властивостей кожного, користуватися додатковими джерелами інформації, осмислювати зміст нової теми, визначати головне, переводити інформацію із короткострокової в довгострокову пам’ять.

Останній етап технології вивчення теми за С. Шевченко- актуалізація та контроль засвоєння знань, які відбувалися у першій половині наступного уроку за регламентом, який був незмінним, знайомим для учнів. Спочатку учні проговорювали протягом трьох - чотирьох хвилин навчальний матеріал в змінних парах «вчитель учень», виставляли один одному оцінки. Якщо кількість учнів в класі була непарною, то роль одного 3 «учителів» виконував С. Шевченко. Далі «головуючий учитель» проводив фронтальне обговорення теми за питаннями, які сам заздалегідь підготовлював, оголошував оцінки за відповіді, за участь в обговоренні. Таке обговорення змісту теми займало п'ятнадцять - сімнадцять хвилин. На наш погляд, застосування роботи в парах, у ролі «головуючого вчителя» допомагало педагогу формувати в учнях навички спілкування, співпраці, обміну досвідом, порівняння різних поглядів, логічного мислення, аналізу, підбиття підсумків, уміння доцільно використовувати набуті знання, сприяло створенню демократичної, доброзичливої атмосфери, впевненості в успіху. Оперативний контроль знань педагог-новатор завершував відтворенням (по пам'яті) учнями у класному зошиті конспекту-схеми, що було незмінним складником уроку. На цю роботу виділялося чотири хвилини уроку. С. Шевченко вважав доцільним використовувати різні методи оцінювання учнівських робіт, зокрема, залучати до перевірки відтворених конспектів самих учнів. Учні виставляли собі самооцінку за вивчену тему, далі точність відтворених листів опорних сигналів контролювали інші учні, які також виставляли кожному учневі оцінку за конспект. Окремий учень порівнював оцінки із самооцінками та виставляв загальну оцінку за тему, що фіксувалася на екрані успішності. У разі виявлення значної розбіжності між оцінкою та самооцінкою, інформація поступала до «головного консультанта», який призначав такому учню консультантів для допомоги в опануванні навчальної інформації. Контроль за ліквідацією прогалин у знаннях таких учнів проходив у формі заліку з теми особисто С. Шевченку.

Слід зазначити, що активна творча самодіяльність школярів супроводжувалася адмініструванням 3 боку вчителя за виконанням всіх обов'язкових етапів процесу 
засвоєння знань. С. Шевченко постійно спостерігав за роботою «вчителів» $\mathrm{i}$ «головуючого вчителя», за необхідності, коректно та доброзичливо втручався в їхню роботу.

Після фронтального обговорення теми та відтворення учнями конспект-схем урок починав вести сам С. Шевченко. Спочатку він підбивав підсумки роботи групи самоуправління: обговорював 3 класом, як провів урок «головуючий учитель», з'ясовував позитивні та негативні моменти, відмічав вдалі питання, вказував, що потрібно допрацювати; потім переходив до вивчення наступної урочної теми.

Другий етап вивчення розділу програми (систематизація та узагальнення отриманих знань) тривав два-три уроки. Перший урок проходив у формі семінару, до якого готувалися заздалегідь. Задля систематизації вивченого навчального матеріалу С. Шевченко використовував творчі завдання та узагальнюючі конспекти (педагог називав їх синтетичними). Другий урок - залік, який, відповідно до педагогічної технології С. Шевченка, грунтувався на широкій взаємоперевірці, що позитивно впливало на успішне засвоєння знань, розкриття творчого потенціалу учнів, розвиток у них аналітичних здібностей, орієнтувало учнів на самостійну оцінку результатів навчальної діяльності, взаємооцінку, формувало впевненість у власних силах та можливостях.

Багаторічний досвід педагога-новатора надає підстави стверджувати, що вміле керівництво вчителем пізнавальною діяльністю учнів, доречне застосування опорних конспектів надавало йому можливість досягти високих результатів у навчанні учнів. Відповідно до технології С. Шевченка листи опорних сигналів сприяли успішному здійсненню навчального процесу, однак не визначали його. Характерною рисою листів опорних сигналів, які використовував педагог, була простота, відсутність будьяких асоціацій. Листи опорних сигналів, створені педагогом-новатором, - це знакові опори, всім зрозумілі логічні схеми навчального матеріалу. Вони, за визначенням С. Шевченка, були логічними модулями теми уроку, в яких наводилися основні факти та поняття, чітко зазначалися причино-наслідкові зв'язки, тобто загальна програма вивчення теми уроку. Обсяг та глибина навчальної інформації залежали тільки від учителя, від того, як він використає методичні прийоми, наскільки переконливо розповість, проілюструє інформацію, організує вивчення тексту підручника тощо.

Удосконалюючи технологію складання листів опорних сигналів, С. Шевченко класифікував знаки, які використовував у процесі побудові логічних схем. Так, за обсягом інформації, яку вони містять, педагог розрізняв знаки: одиничну інформацію; понятійну інформацію; тезисну інформацію. Знаки за зовнішнім зображенням педагог-новатор класифікував так: символічні знаки, що не схожі з явищем або дією, яку вони заміщають; графічні знаки, які використовуються задля відображення розвитку явищ або динаміки дії; знаки-малюнки, що мають візуальну подібність 3 явищами або діями, які вони заміщають; словесні знаки, що складаються 3 окремих слів, складів або окремих літер тих термінів, речень або тезисів, яким присвячена певна змістовна частина теми уроку [9, с. 142].

С. Шевченко експериментально довів, що листи опорних сигналів, які були складені 3 цих знаків, не потребували спеціальної дешифровки. Розповідь учителя та вивчення відповідного параграфа підручника робили їх зрозумілими для учнів. Користуючись логічною схемою як планом, учні видатного педагога-новатора в належному обсязі, грамотно відтворювали навчальну інформацію під час усного опитування.

Слід зазначити, що С. Шевченко у практиці навчальної роботи використовував різні види листів опорних сигналів, кожен 3 яких мав свої особливості та дидактичне призначення. Найбільш поширеними були звичайні листи опорних сигналів, які 
використовувалися у ході вивчення теми уроку. До кожної такої конспект-схеми додавалися логічні завдання, що передбачали обов'язкову роботу 3 відповідним параграфом підручника та стимулювали в учнях процес осмислення навчальної інформації. Також С. Шевченко пропонував особливі листи опорних сигналів у вигляді графіків, що ілюстрували протікання будь-якого процесу та взаємозв'язок його складників. Запропоновані схеми процесів значно підвищували ефективність повторення та узагальнення кількох тем уроків або всього розділу навчального матеріалу. Доречним дидактичним засобом перевірки засвоєних знань, сформованості вмінь на другому етапі вивчення навчальної теми був так званий синтетичний лист опорних сигналів, що узагальнював фактичну інформацію всієї теми, синтезував головне, що було в листах тем уроків- складників навчальної теми. Опори синтетичного листа були найбільш абстрагованими та, на перший погляд, незрозумілими. Проте вони легко розшифровувалися, якщо учень послідовно вивчав теми уроків, користуючись звичайними поурочними листами опорних сигналів.

Спираючись на власний багаторічний досвід, С. Шевченко запропонував загальні рекомендації щодо розроблення листів опорних сигналів: відповідність листа опорних сигналів змістовній структурі певного параграфа підручника (кількість логічних блоків повинна дорівнювати кількості змістовних частин у параграфі); внесення до листів опорних сигналів обмеженої кількості опор, оскільки «зайві» опори викликали труднощі під час письмового відтворення листів та роботі 3 ними (письмове відтворення листа опорних сигналів не повинно перевищувати три чотири хвилини для «середнього» учня); уникнення подібності листів опорних сигналів, що досягалося зміною шрифтів, розташуванням логічних блоків тощо; дотримування розумного балансу під час виділення кольором важливих суджень (занадто «червоний» лист опорних сигналів переставав сприйматися та погано запам'ятовувався); наявність у листі опорних сигналів взаємозв'язків та взаємозалежностей змістовних частин навчального матеріалу [9, с. 152-153].

Отже, використання таких засобів навчання, як різноманітні за дидактичним призначенням схеми теоретичного матеріалу (листи опорних сигналів), було важливим складником освітньої технології видатного педагога-новатора С. Шевченка, оскільки уможливлювало глибоке розуміння, свідоме запам'ятовування великого обсягу навчальної інформації, досягнення цілей навчання найвищого когнітивного рівня. Однак не всі проблеми навчання можна було розв'язати за допомогою правильно складених та доречно використаних символічних записів. Вони лише допомагали подолати певні труднощі вивчення великих блоків матеріалу, прискорювали досягнення запланованих результатів навчання, розв'язання низки дидактичних завдань, а саме: надавали можливість перевірити готовність учнів до сприйняття інформації теми уроку; сприяли свідомому пов'язуванню кожної змістової частини нової інформації 3 певними опорами, що значно підвищувало запам'ятовування, продуктивність домашньої роботи учнів 3 підручником, розвивало у них навички самостійної роботи 3 незнайомим текстом, навички змістовного аналізу, селективності, кодування тексту. Цей досвід потребує цілісного дослідження та актуалізації на сучасному етапі модернізації української системи освіти.

\section{Література}

1. Дидактика современной школы: [пособиедля учителей] / [Кобзарь Б. С., Кумарина Г. Ф., Кусый Ю. А. и др.] ; под ред. В. А. Онищука. - К. : Радянська школа, 1987. - 351 с. 2. Левитес Д. Г.Практика обучения : современные образовательные технологии / Д. Г. Левитес. - Воронеж: МОДЭК; М. : Институт практической 
психологии, 1998. - 288 с. З. Нечепоренко Л. С. Схематические наглядные пособия и методика их применения / Л. С. Нечепоренко. - Каменец-Подольский, 1967. - 231 с. 4. Педагогика / [Абдуллина О. А., Алемаскин М. А., Бабанский Ю. К. и др.] ; под ред. Г. Нойнера, Ю. К. Бабанского. - М. : Педагогика, 1984. - 368 с. 5. Педагогика школы :[учеб. пособ. для студ. пед. ин-тов] / под ред. Г. И. Щукиной. - М. : Просвещение, 1977. - 384c. 6. Столяр А. А. Педагогика математики / А. А. Столяр. Мн. : Выш. шк., 1986. - 414 с. 7. Фридман Л. М. Наглядность и моделирование в обучении / Л. М. Фридман. - М. : Знание, 1984. - 80 с. 8. Фридман Л. М.Педагогический опыт глазами психолога :[книга для учителя] / Л. М. Фридман. - М. : Просвещение, 1987. - 224 с. 9. Шевченко С. Д. Школьный урок : как научить каждого / С. Д. Шевченко. - М. : Просвещение, 1991. - 175 с.

УДК37.02(09)(477)

Вадим Пилипенко

\section{«ЛЕКЦИИ ИМЕЮТ БЫТЬ ЧИТАННЫМИ...» (ДО ПИТАННЯ ОРГАНІЗАЦІЇ О. СТРОНІНИМ ПУБЛІЧНИХ ЧИТАНЬ У ПОЛТАВІ)}

Пилипенко В. В. «Лекции имеют быть читанными...» (до питання організації О. Строніним публічних читань у Полтаві).

Стаття присвячена освітній діяльності Олександра Івановича Строніна у сфері поширення практики читання публічних лекцій. Обгрунтовуються педагогічні, організаторські та адміністративні здібності вчителя в розглядуваному освітньому напрямі. Акцентується увага на тому, що О.Стронін розглядав публічні лекції як цілісний та самобутній проект позашкільної освіти.

Ключові слова: О. Стронін, жіноча гімназія, навчання, недільна школа, публічні лекції.

Пилипенко В. В. «Лекции имеют быть читанными...» (к вопросу организации А. Строниным публичных чтений в Полтаве).

В статье рассматривается деятельность Александра Ивановича Стронина в сфере распространения практики чтения публичных лекций. Обосновываются педагогические, организаторские и административные умения учителя в данном образовательном направлении. Акцентируется внимание на том, что А. Стронин рассматривал публичные лекции как целостный и самобытный проект внешкольного образования.

Ключевые слова: А. Стронин, женская гимназия, обучение, воскресная школа, публичные лекции.

Pilipenko V. V. «Lectures are to be read ...» (to the organization A. Stronina public readings in Poltava).

The article about A. Stronin`s educational activity in the field of public lectures. Author is substantiated pedagogical, organizational and management teachers ability as public lectures founder. Attention is accented on that A. Stronin considered the public lectures as holistic and original project of out of School Educational.

Key word: A. Stronin, Sunday school, women's gymnasium, education, public lectures,.

Одними із пріоритетних принципів реалізації Державної національної програми «Освіта» («Україна XXI століття») визначено іiі багатоукладність і варіантність, щопередбачає створення можливостей для широкого вибору форм освіти, засобів 